\title{
STUDENT PERCEPTION ON BUSINESS ETHICS ${ }^{1}$
}

\author{
Eko Suwardi \\ Department of Accountancy \\ Faculty of Economics and Business, Universitas Gadjah Mada \\ (e.suwardi@ugm.ac.id; fisaqori@yahoo.com) \\ Arika Artiningsih \\ Universitas Gadjah Mada \\ M. Ridwan Novmawan \\ Universitas Gadjah Mada
}

\begin{abstract}
Many research conducted on the behavior of business persons and their perception on business ethics. However, rarely similar study deals with the perception of students on business ethics. Indeed, students are our future generation who are going to have substantial role in Indonesian business and economy. Therefore this study focuses on students as a proxy for future business players in this country (Trawick and Draden, 1980). We compare among groups of students based on their maturity, formal business ethic education, gender and specific professional backgrounds. The results of analysis show that in general students have good perception on business ethics. Further, there is a significant different perception on business ethics among students with different academic maturity, professional background. Student with business background are less ethical compare to those are with non-business background. This may consistent with previous evidence found that ethical principles need to be introduced more to business students. In contrast, there is no different perception on business ethics among student with different gender groups and formal business ethics course. This could be business ethics formal education takes time to be internalized by participants or student with no formal business ethics course also learn business ethics from other sources.
\end{abstract}

Keywords: students, perceptions, business ethics

\section{INTRODUCTION}

Some research deals with perception and attitude of students, academicians and business persons conducted in many developed countries. Sample used in those studies are also varies, ranging from a school level, a national level to an international level. Beltramini et al. (1984) studied the student perception on business ethics using a sample that consists of students across the states in the US. Roxas and Stoneback (2004) investigated whether gender has influence on ethical decision. Borkowski and Ugras

\footnotetext{
${ }^{1}$ This paper was presented at Asia Pacific Business Research Conference, 13-14 February, 2013, Kuala Lumpur, Malaysia.
}

(1998) study literature on Business Students and Ethics: A Meta-Analysis by scrutinizing both published and unpublished studies on business to observe whether there is a consensus on the influence of gender and faculty (professional) backgrounds. From those studies they found that 47 studies use gender variable, 35 studies use age variable and 30 studies use faculty (professional background) variable. These studies signify that many variables used and the results in business ethics research are inconclusive. Inconclusive results and latest world financial scandals seem to have more attention among academician to further investigate the determinants of ethical decisions. 
Unlike in developed countries, in Indonesia is lack of study deals with business ethics although many business scandals happened due to lack of ethical compliance, namely Global Bank, Lapindo, Buyat Minahasa, and Century Bank cases. Therefore, this study investigates the perception of student (who are future business persons) on business ethics given the academic maturity, gender, formal education in business ethics and professional background.

The results of analysis based on the sample we use indicate that there is a significant different perception on business ethics between academically mature and less academically mature students. The same results also happen to student with different professional backgrounds. In contrast, there is no different perception on business ethics among student gender groups and students groups who have formal business ethics education and student group with no formal business ethics education.

This paper is organised as follows. After introduction, literature review and hypothesis development are presented. Further, research method and data are laid out to show the method and data used in this paper. Finally, this paper presents data analysis, results and conclusions.

\section{LITERATURE REVIEW AND HYPOTHESIS DEVELOPMENT}

\section{Business Ethics}

Ethics is principle agreed upon that governs individual and groups in a certain place, society or firm. This principle is used to benchmark whether certain behaviour is right or wrong (Velazquez, 2006) Ethics is also refers to principle that must be followed by individual in a certain organization. When we refer to a set of rule or regulation which specifically regulate accountant (accounting professions) then it called professional ethics of accountants.

Further Velazquez (2006) also defines ethics is a decipline that study individual and society moral standards. The standards includes norm related to behaviour wihich is true or false according to moral standards. In the society, there are many people and groups of people who share a common objectives. In acheiving the objectives, the people organized themselves into an institution. Many institutions in the society namely: family, charity, politics, law and corporate or economic institution. Among them, economic intitution has dominated other institution in influencing the moral standards of society (Velasquez, 2006). Economic institution is designed to acheive two objectives: 1) good and services required by society and 2) distribute the goods and services to the consumers.

An Economic institution which has substantial influence in community are corporations which have legal entity. A corporate is treated as a legal entity which has legal right as an individual does. Modern corporates serve investors, management, employees and society who become consumer and a part of social environtment.

In its operation, a corporate or business deals with various stakeholders both internal and external stakeholders. Beyond the regulation in its daily activities, a business need code of conduct which is agreed upon to self regulate among the business and its stakeholders. The code rule of conduct is derived from ethical norms which is widely accepted by society. Business ethics is an implementation ethical principles in business transaction (Velasquez,2006).

\section{Level of Maturity, Formal Education, and Business Ethics}

Trawick and Draden (1980) stated that academicians are responsible for preparing future managers. Education makes people become more ethically sensitive and are able to argue in ethical matter eventhough knowledgeble persons are not always ethical. This statement indicates that ethics may be taught in formal education.

On the other hand, Rohatyn (1987) ethics must be experienced since chilhood at home, school and church, therefore, it is doubt to be taught. Lane, Schaupp, dan Parsons (1998) also contend that education may change ethical behaviour temporarily but not permanently.

Although some literatures indicate that education may only stimulate short term ethical 
awareness, many business schools introduced business ethics subjects in their curiculum, or ethical substance is embeded into many subjects or courses. This practices also supported by findings of Davis dan Welton (1991). They found that education is able to change ethical awareness. Further, age and maturity are also associated with their perception on business ethics.

Based on the above literature, ethical perception of students may develope in line with the level of maturity of student during their study at the university. Therefore, the first hypothesis of this study is as follow.

$\mathrm{Ha}_{1}$ : The level of ethical perception on business ethics of students is different in line with the maturity level of the students.

This hypothesis will be tested on undergraduate students and graduate students. Should this hypothesis is supported, then it provides evidence that ethical perception is associatred with the level of maturity.

The first hypothesis is supported by two hypotheses.

1) ha $a_{1 a}$ : The perception on business ethics of students is different between that of junior undergraduate students and that of senior undergraduate students.

2) ha $\mathrm{lb}_{\mathrm{b}}$ : The perception on business ethics of students is different between that of senior undergraduate students and that of graduate students. Junior undergraduate students are students who seat at semester 1, 2 and 3 and seniors are those who are in semester 4 or above.

The second hypothesis is related to idea that ethics may be taught in formal education. Thus the following hypothesis will be tested using comparation between the level of ethical awareness of students who have already taken business ethics class and that of those who have not.

$\mathrm{Ha}_{2}$ : The perception on business ethics of students who have taken business ethics class is diferrent from that of who have not

\section{Gender and Business Ethics}

Hypothesis related to gender socialization approach, that there are different characteristics between male and female, therefore, they have different orientation in creating moral value (Kohlberg, 1969). Gilligan (1982) expanded the study based on gender orientation. For female, the frame of moral quations include caring, empathy and compassion, whereas for male, the frame of moral questions are right, justice and fairness.

Gender socialization approach argues that female and male have differnt moral respon to a certain situation in the similar condition. Male seeks successful based on competition, tend to brake the rule, whereas female tends to seek harmony, obey the rule, care on the way they they acceive the objectives. (Betz dan shepherd, 1989). Gender identity theory sates that gender becomes core of personality that developes moral value, therefore formal ethical education cannot change the moral value. (Roxas dan Stoneback, 2004).

Meanwhile, Structural approach argues that the difference response between male and female is not because the gender itself, rather early socialization and the role of person (occupation of role). This indicates that male and female within similar work environment tend to heve similar ethical response (Betz dan Shepherd 1989).

Barkowski dan Ugras (1998) conducted meta analysis method on research in business ethics published between 1985-1994, found that 47 reseacrh were analysed based on gender. Among the 47 articles, 23 of them resulted significant difference ethical response between the gender, 16 articles resulted insignificant difference and the rest 8 articles resulted mix findings. The results showed that female tends to behave ethically than male does. In accounting and business education, Adkins dan Radtke (2004) found that female tends to assume more ethical principles than male does. The same result was found in business ethic education (Beltramini et.al.,1984).

Understanding the difference ethical response between male and female is getting more important because recently the number of female 
who hold important position in business and other workfoce incearse signficantly (Roxas dan Stone Back, 2004).

Based on these arguments, the fourth hypothesis may derived as follow:

$\mathrm{Ha}_{3}$ : There is different perception on business ethics between male and female students.

\section{Professional and Busisness Ethics}

Many studies indicate that business professionals have lower ethical values compare to those of other professionals in other industries and some business scandal may be categorized as illegal and crime (O’Clock dan Okleshen, 1993). This findings create awareness of the important of ethical value to be introduced early as possible in business profesional education.

As in fact many ethical scandals involved business professionals, created question whether business professionals are lack of ethical values compare to those of other professionals? To answer such question, this study also compares the etical value response of business professionals (as represented by accounting and business students) and other professionals as represented by student in other faculty (pharmacy student). Those two groups of students are assumed to be appropriate because the have similar curiculum professional ethics, accountant ethical conduct and parmacyst ethical conduct. Therefore, the next hypothesis is as follow.

$\mathrm{Ha}_{4}$ : There is different perception on business ethics between business profesional students and non business professional students.

\section{POPULATION DAN SAMPLE}

The population of this study is Indonesian students because they are representing future Indonesian leaders in many sectors. The sampling method is purposive sampling method. For business professional are represented by students of the Faculty of Economics and Buseness at the Accounting and Business departments, whereas other profesionals are represented by students from Faculty of Pharmacy. All students are from Gadjah Mada University because its student body is representative for Indonesian

\section{RESEARCH METOD}

This study uses closed ended questions consist of ten questions that provide six options response from sore 1 to score 6 to obtain the perception of student on business ethics. This questionary is tested in term of its validity and reliability. Data obtained from the questionary then compared and tested using independent $t$ test (Cooper and Schindler, 2003).

\section{ANALYSIS}

Table 1 shows ten questions of business ethics issues and decriptive statistics on the level of business ethics response or ethical values of respondends. The ethical response is scaled from very unimportant (1) to very important (6) on certain business ethics issues.

Each business ethics issue earned different score, however, most of them are 5 (important) and 6 (very important). These indicate that most of students have ethical response between important and very important mean that most student care to ethical value in solving business problems. The highest average score is on the important ethics in profession $(5,61)$, whereas the lowest average score is on the important ethics in the individual decission at the individual level (5.18).

The ethical response of some characteristics of students on business ethics in the various issues are presented in the Table 2. First, comparing the ethical response of the students in different level of maturity. The results indicate that maturity of students differenciates students' ethical response. Undergraduate students have ethical response score 52.8 while graduate students have that of 54.82 and those two scores are significantly different, this means that the more mature students tend to be more ethical. 


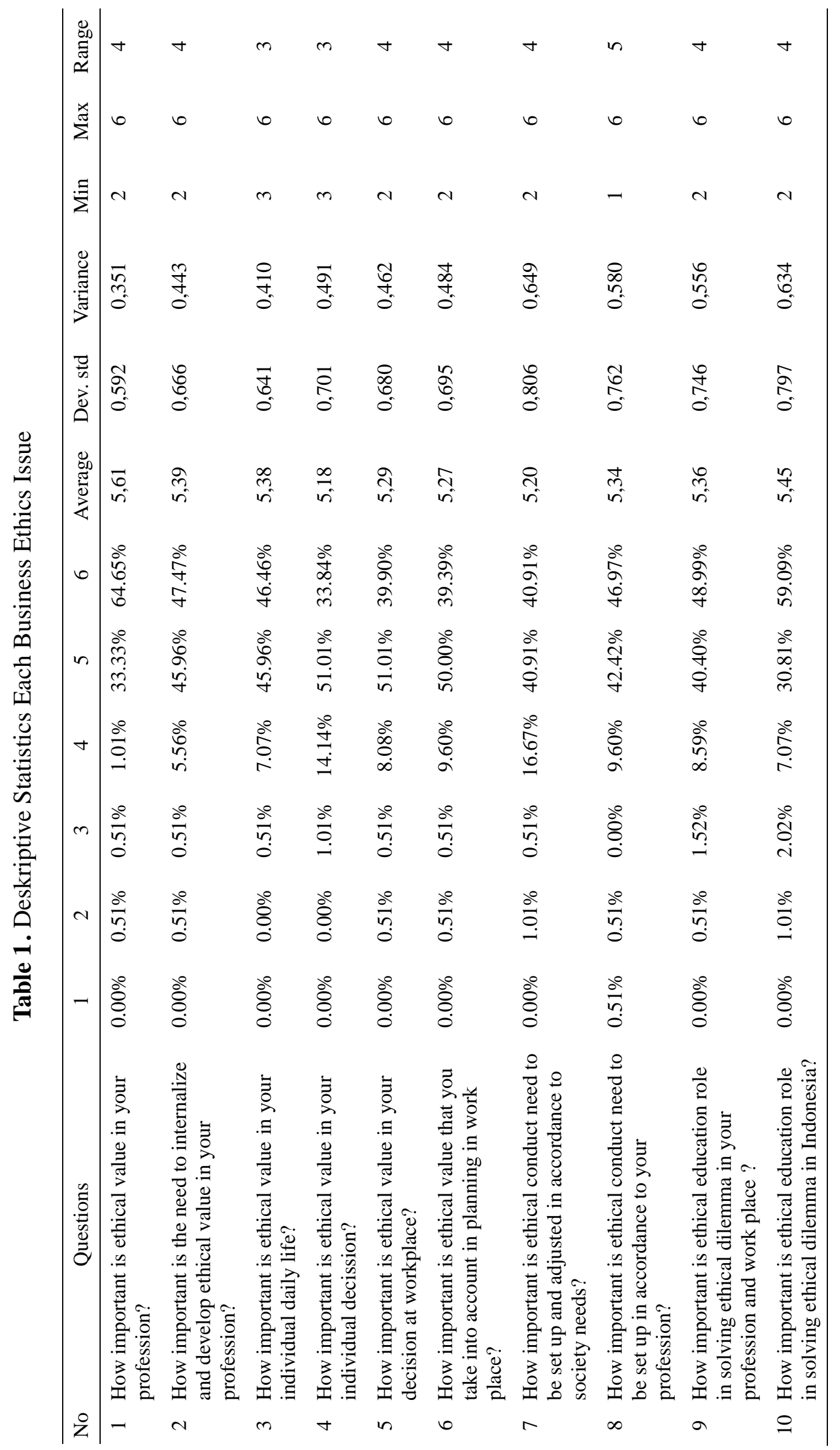




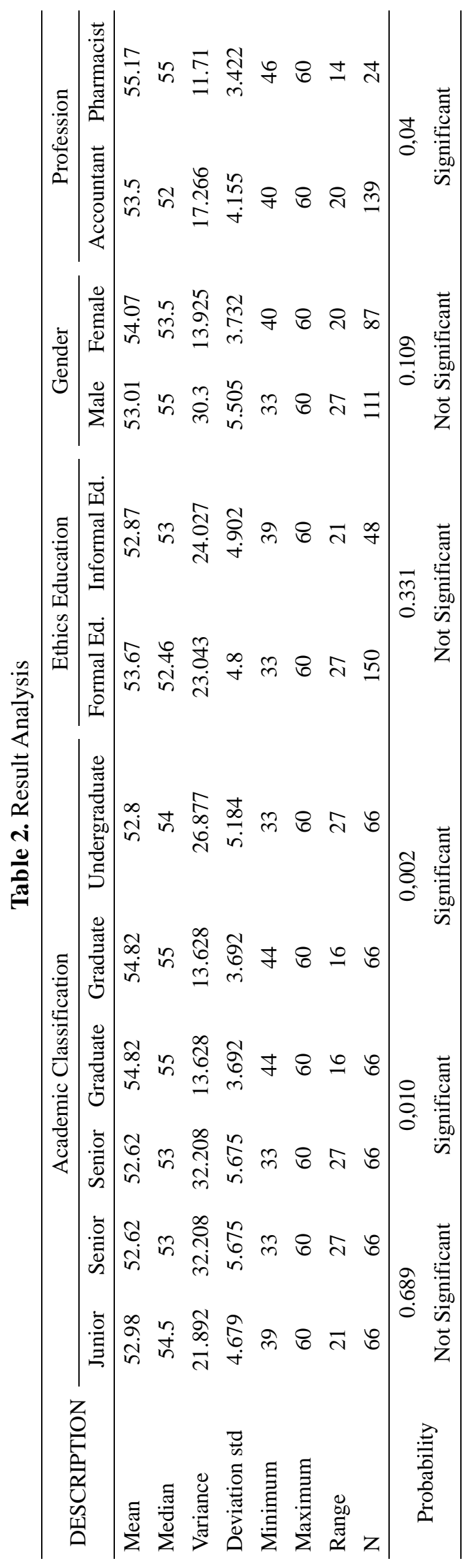


When the level of maturity among undergraduate students are compared, the results are unable to find any defferent score on ethical response among groups of undergraduate level (between juniors and seniors). However the level of ethical response between senior undergraduate and graduate students are different. This results signify the support on the maturity hypothesis. An interesting findings is junior students has score ethical response 52, 98 and senior have an average score 52,61.

Education ethics indicates that there is no difference score on ethical response of students who have taken Business Ethic class and those who have not. This means that formal education unable to influence the score response on ethics. Even so, the score of students who have taken business ethic class $(53,67)$ is higher than that of who have not taken business ethics class $(52,87)$. This finding support value development theory as stated by Rohatyn (1987) dan Lane et.al (1998); ethics is something that has been habitualized since childhood and not because formal course at school or university.

Next, gender group based analysis shows that male and female do not have any differnce score in ethical response, this means that gender does not have any influence on the level of ethics. This is may be both male and female students are in the same environmets as stated in the sructural approch. Even so the male $(53,01)$ score is lower that that of female score (54.07)

The last two column, shows that the score on ethical value of business student $(52,87)$ is less that that of parmacy student $(55,17)$, this means that business students are less ethical than pharmacy students. This findings may support by research results indicating that business student is less ethical perception than non-business students.

\section{CONCLUSIONS}

This study investigates the perception of students on business ethics. The sample consists of students at the Business, Accounting and Pharmacy departments. The results indicate that students have a high ethical awareness (perception) especially when the issue is related to their professions.

The surprised finding is that business students have less ethical business awareness compared to pharmacy students do. This result may explain the consistency of many corporate scandals committed by management of the firms. The perception on business ethics of students is also influenced by the maturity level of the students. Gender factor, in contrast, does not have any power to distinguish level of ethical perception among male and female students.

\section{REFERENCE}

Adkins, Nell dan radtke, Robin R. 2004. "Students and Faculty Members Perception of the Importance of Business Ethics and Accounting Ethics Education: Is there an Expectation Gap?”. Journal of Business Ethics. Vol. 51, No. 3 (Mei): 279-300.

Beltramini, Richard F., Peterson , Robert A., dan Kozmetsky, George. 1984. "Concerns of College Students regarding Business ethics”. Journal of Business Ethics. Vol. 3, No. 3 (Agustus) :195-200.

Betz, M., L. O’Connell dan J. Shepherd. 1989. "Gender Differences in Proclivity for Unethical Behaviour”. Journal of Business Ethics. Vol. 8, :321-324.

Borkowski, Susan C. dan Ugras, Yusuf J. 1992. "The Ethical Attitudes of Students as a Function of Age, Sex and Experience". Journal of Business Ethics. Vol. 11, No. 12 (Desember): 961-979.

Cooper, D.R. dan Schindler, P.S.2003. Business Research Method. Boston: McGraw-Hill

Davis, James R. dan Welton, Ralph E. 1991. "Professional Ethics: Business Students' Perceptions”. Journal of Business Ethics. Vol. 10, No. 6 (Juni): 451-463.

Gilligan, C. 1982. In a Different Voice. Harvard University Press. Cambridge.

Kohlberg, L. 1969. Stage and Sequence: The Cognitive-Development Approach to Socialization. A. Goslin (ed.). Handbook of 
Socialization Theory and Research. Rand McNally, Chicago.

Lane, Michael S., Schaupp, Dietrich, Parsons, Barbara. 1988. "Pygmalion Effect: An Issue for Business Education and Ethics”. Journal of Business Ethics. Vol. 7: 223-229

Rohatyn, F.G. 1987. "Ethics in America's Money Culture”. New York Times (Juni): A27.
Roxas, Maria dan Stoneback, Jane Y. 2004. "The Importance of Gender across Cultures in Ethical Decision -making”. Journal of Business Ethics. Vol. 50, No. 2 (Maret): 149-165.

Trawick, I.F. dan Darden, E.R. 1980. “ 'Marketers' Perceptions of Ethical Standards in the Marketing Profession: Educators and Practitioners". Review of Business and Economic Research. Vol. 16: 1-17. 